\title{
Retrospective Analysis of Plagiaristic Practices within a Cinematic Industry in India - a Tip in the Ocean of Icebergs
}

\author{
Paneerselvam Umamaheswaran ${ }^{1}$ - Sharavan Ramachandran ${ }^{2}$. \\ Shivadas D. Sivasubramaniam ${ }^{3}$ (D)
}

Published online: 24 January 2020

(C) The Author(s) 2020

\begin{abstract}
Music plagiarism is defined as using tune, or melody that would closely imitate with another author's music without proper attributions. It may occur either by stealing a musical idea (a melody or motif) or sampling (a portion of one sound, or tune is copied into a different song). Unlike the traditional music, the Indian cinematic music is extremely popular amongst the public. Since the expectations of the public for songs that are enjoyable are high, many music directors are seeking elsewhere to "borrow" tunes. Whilst a vast majority of Indian cinemagoers may not have noticed these plagiarised tunes, some journalists and vigilant music lovers have noticed these activities. This study has taken the initiative to investigate the extent of plagiaristic activities within one Indian cinematic music industry. A list of plagiarised songs was produced by using YouTube® searches for "comparative videos" made by the vigilant music lovers about accused/detected music plagiarism. Some of these individuals were also interviewed to understand their views on this. During the investigation, it was possible to identify a vast number of plagiarised tunes, snippets, or even the full songs. In fact, some of these examples' dates to 1954, during the era when no one would have noticed plagiarism. The paper would highlight the similarities of these music files. It will also show some examples of the excuses/denial given by the composers and would try to highlight the attitudes of general public towards these types of activities.
\end{abstract}

Keywords Integrity $\cdot$ Music plagiarism $\cdot$ Sampling $\cdot$ Collaborative $\cdot$ Cinematic music $\cdot$ Creative art

Shivadas D. Sivasubramaniam s.sivasubramaniam@derby.ac.uk

Paneerselvam Umamaheswaran ptuma87@gmail.com

Sharavan Ramachandran

sharavan.ramachandran@ttuhsc.edu

Extended author information available on the last page of the article 


\section{Introduction}

From the beginning of this century, public awareness on "academic integrity" and avoiding plagiarism has considerably increased. The concept is wilfully embraced by academics around the world and governments are in consultation with respective higher education organisations to curb this academic offence (Glendinning 2014). However, it is not clear whether similar focus has been made in the music industry. For many years, music industry is controlled by "customary laws", which are not obligatory and therefore subject to violation (Stav 2014). In contrast, as a "creative art", music is subject to Intellectual Property, and Copyright Laws. Music plagiarism is defined as using tune, or melody that would closely imitate with another author's music without proper attribution (Keyt 1988; Stav 2014). Plagiarism is relevant to different musical styles in different ways. It may occur either by stealing a musical idea (a melody or motif) or sampling (a portion of one sound, or tune is copied into a different song). Melody (or motif) is a linear succession of musical tones which are composed of pitch (or memorable series of pitches) and rhythm (or even tone) (Music-Dictionary - www ${ }^{1}$ n.d.). Therefore, the listener would easily detect the "melody", if it is plagiarised to produce another song. However, it is worth noting that melodies are often rewritten in another language via collaborative partnerships. For example, in 2014, Indian music composer AR Rahman collaborated with American recording artist will.i.am and singer Cody Wise, to produce a single called "It's my birthday" (www ${ }^{2}$ n.d.) which is based from a 1994 Tamil song "Urvasi Urvasi" (www ${ }^{3}$ n.d.) by AR Rahman, from the soundtrack of an Indian film. Although, it was alleged that will.i.am had plagiarised the song, it was later revealed (by both parties) as a collaborative effort.

One the other hand, sampling is simply using portions of one recording into another or clipping (removing) out portions, rearranging them to produce new music (Stav 2014). Something similar to "patch-work" plagiarism. It would be often difficult to detect by common listeners. The latter is usually governed by agreements such as the Berne Convention for the Protection of Literary (BCPL), or Performances and Phonograms Treaties Implementation Act (PPTI) (found within World intellectual property organisation (WIPO) Copyright treaty$\mathrm{www}^{4}$ n.d.). These treaties provide creators the means to control how artists creations (including musicians) are used, by whom, and on what terms. According to these conventions any artists may obtain prior authorisation for sampling usually by paying an upfront fee and/or agreeing to share the royalties to the original artist (Keyes 2014; McDonagh and Luke 2012). A good example of such agreements is the Holly Valances "Kiss Kiss", (www ${ }^{5}$ n.d.- released in 2002) an English language rewrite of Tarkan's (Turkish singer) "Şımarlk" (www ${ }^{6}$ n.d.originally composed by Sezen Aksu in 1997). Likewise, there is exemption for reusing/ copying similar rhythm (known as "chord progression"), the order in which the base, chords and beats are played in a song. In other words, the base beat and chords can be nearly identical, and this would not be an issue. This is especially true in Carnatic music as it is based on different "Thalas" (i.e. rhythmic beat or strike) (Nettl 2010; Behrens 2004). As can be seen above, like any other copyright regulations, there is room for collaborative, pre-arranged sampling in music industry.

However, the act of music plagiarism is committed, if a composer (or artist) copies the melody or carries out unauthorised sampling; especially when two or more songs are matching with melody. In fact, several world-famous names within English pop, such as George Harrison (The Beatles), and the Gallagher brothers (Oasis) have been accused of "borrowing" musical tone, and/or rhythms from others (Matt Melis and Michael Roffmanon, January 2018 $-w_{w w}{ }^{7}$ n.d.). There were some, memorable lawsuits against many American pop stars (www ${ }^{7}$ 
n.d.). Unlike the Western countries, the music industry in the East, especially in India has different domains. Those based on traditional music rhythms that are believed to be originated in ancient times. These include Carnatic (Southern India), folk (culture-specific) and Hindustani (Northern India) music. On other hand, music that is inter-woven within cinematic industry. This second type is mostly a mix of traditional and Western music.

Film industry has been thriving in India better than the Hollywood industry (The Indywood report, September 2016). The industry has been well established in different cities based on the languages (such as Hindi, Tamil, Telegu, Kannada Malayalam etc.). Almost all the Indian films have at least 4 to 8 songs, may they be duet, or be the ones with philosophical message. Unlike the traditional music, the cinematic music is extremely popular amongst the people. The industry has become profitable and many new (so called) "music directors/composers" are being born almost every year. Since the expectations of the general public for songs that are enjoyable and/or would make everlasting impressions are high, many music directors are seeking elsewhere to "borrow" tunes. Whilst a vast majority of Indian cinemagoers may not have noticed these plagiarised tunes or "songs that were written inspired by another tune", some journalists and vigilant music lovers have started noticing these activities and publicising these on main media including YouTube®. In fact, the accusations within the social media and YouTube ${ }^{\circledR}$ covers songs (and composers) of entire cinema industry (including Hindi, Tamil, Telegu, Kannada, Malayalam etc.) However, these types of small-scale publicising have not resulted in a mass propaganda against these rogue music directors. Therefore, this study aims to investigate the extent of plagiaristic activities within Indian cinematic music industry. Since this is an initial study, we focussed on songs within one language.

\section{Methodology}

This retrospective study was carried out using YouTube ${ }^{\circledR}$ searches for "comparative videos" made by the vigilante music lovers and published news articles about accused/detected music plagiarism. The YouTube® searches were conducted from February 2018 to January 2019. Some of the vigilantes, music lovers, and sources closed to some composers were also interviewed to understand their reflective conscious views on this. Personal opinions about music plagiarism (within South-Indian Tamil) of 15 vigilantes/music lovers and 3 individuals from the music industry itself are reported herein (as phenomenology inspired analysis). This, together with authors own research on the extent of this theft, forms the basis of this initial study. In addition, as an investigative journalist, the first author carried out research on the extent of this music theft (rip-offs and sampling) within cinematic industry of India.

Although this type of music plagiarism is widespread within Indian cinematic industry, due to time constraints, this initial paper has focussed on one specific industry (one language Tamil). The study was conducted under UNESCO's 'Norms of Journalistic Conduct' (Press Council of India - UNESCO 2010).

\section{Results and Discussion}

A collection of cases (songs) that have been plagiarised by different music composers within Tamil cinema are summarised in Tables 1 and 2 with YouTube ${ }^{\circledR}$ links to original songs for comparison. Table 1 contains a compendium of plagiarised (or heavily sampled) songs after 1990 
Table 1 Plagiarised Tamil songs after 1990 (with their originals)

Plagiarised Tamil Song* Original song or music

Film: Dev

Song: Anangae Sinungalama (Please click here)

Composer: Harris Jayaraj

Release date: 14th February 2019

Film: Irumugan

Song: Helena (Please click here)

Composer: Harris Jayraj

Release date: 20th February 2017

Film: Engyum Kaadhal

Song: Engyum Kaadhal (Please click here)

Composer: Harris Jayraj

Release date: 6th May 2011

Film: Engyum Kaadhal

Song: Nangai (Please click here)

Composer: Harris Jayraj

Release date: 6th May 2011

Film: Adhavan

Song: Varayo (Please click here)

Composer: Harris Jayraj

Release date: 17th October 2009

Film: Kathalil Vizhunthen

Song: Unakena nan (Please click here)

Composer: Harris Jayraj

Release date: 26th September 2008

Film: M. Kumaran Son of Mahalakshmi

Song: Welcome Boys/Girls. (Please click here)

Composer: Srikanth Deva

Release date: 1st October 2004

Film: Baba

Song: Ekamevadmitheeyam. (Please click here)

Composer: AR Rahman

Release date: 15th August 2002

Film: Kushi (only the beats copied)

Song: $O$ Vennila. (Please click here)

Composer: Mani Sharma

Release date: 26th April 2001

Film: Kushi (only the beats copied)

Song: Mottu onru. (Please click here)

Composer: Mani Sharma

Release date: 26th April 2001

Film: Kushi

Song: Mac Mac Mac Macarena (Please click here)

Composer: Mani Sharma

Release date: 26th April 2001

Film: Citizen

Song: Hey I like you (Please click here)

Composer: Deva

Release date: 8 June 2001

Film: Citizen

Song: Pookara (Please click here)

Composer: Deva

Release date: 8 June 2001

Film: Shajahan (Opening line only)

Song: Minnalai pidithu. (Please click here)

Composer: Mani Sharma
Album title: Thriller

Song: Billie Jean (Please click here)

Composer: Michael Jackson

Release date: 30th November 1982

Album title: Trap Queen (Single)

Song: Trap Queen (Please click here)

Composer: Fetty Rap

Release date: 30th November 1982

Album title: Konvicted

Song: Doesn’t Matter (Please click here)

Composer: AKON

Release date: 19th January 2007.

Album title: Bad

Song: The Way You Make Me Feel (Please click here)

Composer: Michael Jackson

Release date: 9th November 1987

Album title: Mongolian Song

Song: Buffalaxed (Please click here)

Artist: Mongol Goyol

Release date: 1994

Album title: Unfaithful

Song: Unfaithful (Please click here)

Composer: Rhianna

Release date: 2nd May 2006

Album title: Malaysian song

Song: Hati Kama (Please click here)

Composer: Siti Nurhaliza\& Noranliza Idris

Release date: 1999

Album title: The Untouchables

Song: Theme music (Please click here)

Composer: Ennio Morricone

Release date: 18th September 1987

Album title: Lágrimas

Song: Canção do Mar (Please click here)

Composer: Edição

Release date: 1996

Album title: Dangerous

Song: Why You Wanna Trip On Me (Please click here)

Composer: Michael Jackson

Release date: 1991

Album title: Where Do You Go?

Song: Where Do You Go? (Please click here)

Composer: No Mercy

Release date: 1996

Album title: Dedicated to

Song: I Feel Lonely (Please click here)

Composer: Shasha

Release date: 16 November 1998

Album title: ABBA: The Album.

Song: Take a Chance on Me (Please click here)

Composer: ABBA

Release date: January 1978

Movie: The Ghost and The Darkness

Song: Theme music (Please click here)

Composer: Jerry Goldsmith 
Table 1 (continued)

Plagiarised Tamil Song*

Release date: 14th November 2001

Film: Priyamanavale

Song: Welcome Boys/Girls. (Please click here)

Composer: SA Rajkumar

Release date: 26 October 2000

Film: Rhythm (Ripped off beat)

Song: Nadhiye nadiye (Please click here)

Composer: Ganesh Bharadwaj

Release date: 15 September 2000

Film: Vaali

Song: April Mathathil (Please click here)

Composer: Deva

Release date: 30th April 1999

Film: Vaali

Song: Oh Sona (Please click here)

Composer: Deva

Release date: 30th April 1999

Film: Mugavari

Song: Oh Nenje (Please click here)

Composer: Deva

Release date: 25th October 1999

Film: Mugavari

Song: Hey Keechu Kiliye (Please click here)

Composer: Deva

Release date: 25th October 1999

Film: Mugavari

Song: Poo Virinchachu (Please click here)

Composer: Deva

Release date: 25th October 1999

Film: Neruku Ner

Song: Akila Akila (Please click here)

Composer: Deva and K. V. Anand

Release date: 6th September 1997

Film: Iruvar

Song: Hello Mr. Ethirkatchi (Please click here)

Composer: AR Rahman

Release date: 14 January 1997

Film: Ullathai Allitha

Song: Azhagiya laila (Please click here)

Composer: Sirpy

Release date: 15 January 1996

Film: Indian

Song: Akkadanu (Please click here)

Composer: AR Rahman

Release date: 29th August 1996

Film: Karnaa

Song: Hey Shaba (Please click here)

Composer: Vidyasagar

Release date: 14 April 1995

Film: Muthu

Song: Kuluvaliye (Please click here)

Composer: AR Rahman

Release date: 23rd October 1995

Film: Muthu (Background Rhythm)

Song: Thillana Thillana (Please click here)

Composer: AR Rahman
Original song or music

Release date: 11th October 1996

Album title: We See the Same Sun

Song: Coco jumbo (Please click here)

Composer: Mr. President

Release date: 30th November 1996

Album title: Released as Single

Song: Strange of women (Please click here)

Artist: Deep Purple

Release date: 1971

Album title: Released as Single (Ripped off beat)

Song: Strange Kind of Woman (Please click here)

Artist: Deep Purple

Release date: 1971

Album title: Suzanne (VOF de Kunst song)

Song: Susana (Please click here)

Artist: The art company

Release date: 1984

Album title: Backstreet Boys

Song: Get Down (You're The One For Me) (Please click here)

Artist: Backstreet Boys

Release date: 1997

Album title: I Believe

Song: Enemies (Please click here)

Artist: Dr. Alban

Release date: 1997

Album title: That thing you do!

Song: - That thing you do (Please click here)

Artist: The Wonders

Release date: 4th October 1996

Album title: Released as a single

Song: Buffalo Soldier (Please click here)

Artist: Bob Marley and the Wailers

Release date: 1983

Album title: Memphis Stomp (Opening lines)

Song: Piano (Please click here)

Composer: Dave Grusin

Release date: 1993

Album title: Arabic Song

Song: Ahla Ma Feki - (Please click here)

Composer: Hesham Abbas

Release date: 1995

Album title: Love of common people

Song: Love of the Common People (Please click here)

Artist: Paul Young

Release date: 1970

Album title: Khalid-Chebba

Song: Chebba. (Please click here)

Composer: Khaled

Release date: 4th February 1993

Album title: Fontella Bass - Rescue Me

Song: Rescue me. (Please click here)

Artist: Fontella Bass

Release date: 1965

Album title: Beautiful

Song: Night Bird. (Please click here)

Artist: Deep forest 
Table 1 (continued)

\begin{tabular}{ll}
\hline Plagiarised Tamil Song* & Original song or music \\
\hline Release date: 23rd October 1995 & Release date: 1992 \\
Film: Gentleman & Album title: Osibirock \\
Song: Paakkathey Paakathey (Please click here) & Song: Keelele. (Please click here) \\
Composer: AR Rahman & Artist: Osibisa \\
Release date: 13th July 1993 & Release date: 1974 \\
Film: Chatriyan & Album title: Sound of Music \\
Song: Pootukkal potaalum (Please click here) & Song: My Favourite things (Please click here) \\
Composer: Ilaiyaraaja & Composer: Richard Rodgers \\
Release date: 17 October 1990 & Release date: 29 March 1965 \\
\hline
\end{tabular}

*The famous composers have been identified by different colours [Brown - Harris Jayraj (HJ); Green= Ilaiyaraja (IR); Blue - AR Rahman (ARR)]

(recent songs). Likewise, Table 2 contains plagiarised Tamil songs from before 1990. As mentioned in methodology, the data was collected via YouTube ${ }^{\circledR}$ searches. As all authors do not have music expertise, we concentrated on songs that are easily recognisable similarities (i.e. for blatantly obvious ripped off music) by the listeners. In other words, we are not claiming this is an exclusive list of all plagiarised songs. Instead, the data presented here are the results of an initial attempt to highlight the extent of this unethical practice with Tamil cinema. Interestingly, we managed to discover songs from the famous and well-respected music composers namely Harris Jayaraj (HJ), Ilayaraja (IR), AR Rahman (ARR), Deva (D), MS Viswanathan (MSV) who have been historically known as "creators of music in Tamil cinema". In fact, IR and ARR received an honorific title of "Music maestro". IR is recognised as the first Asian to compose a full symphony with the Royal Philharmonic Orchestra in London (Symphony of Success - www ${ }^{8}$ n.d.). Yet, our research has shown similarities in their early melodies with other international songs. Equally, many upcoming music composers like Yuvan Sankar Raja (son of Ilayaraja), Anirudh Ravichander, and Iman have used other melodies (or samples) as the base for several of their compositions. Due to the fact this manuscript is intended to attract international audience and highlight the plagiaristic activities within Indian cinematic industry, we are discussing songs that are plagiarised (or sampled) from famous Western and other melodies and songs. This would aid the audience to understand the similarities between original and plagiarised versions. Readers are urged to compare the originals and plagiarised (sampled) version by listening to the links provided (in the online version of this manuscript).

Starting from the melody of a recent Tamil music video composed and released by HJ called 'Anange Sinungalama' (the first song highlighted in Table 1) on 14th of December 2018 (for a film called Dev), this resembles the 1983 hit 'Billie Jean' by Michael Jackson. In fact, different Indian stand-up comedians have ridiculed HJ's copying of famous melodies to produce his own songs ( $w_{w w}^{8}$ n.d.). The extent of his plagiaristic activities is so high that one stand-up comedian Alexander from Evam has joked that "the music director is capable of being influenced by even the choir songs during Sunday mass" (Indian Express, 2019 - www 9 n.d.). HJ's other hit song called "June Ponal" featured in Tamil film called "Unnale unnale" in 2007, which was simply copied from "All Rise" by Blue, a Western music group in 2001 (second song in Table 1). In addition, HJ is also famous for sampling; his sampling activities are so high that the beats of his own songs resemble each other. This was in fact ridiculed by another stand-up comedian called Jagan Krishnan, who went to the extent of sending his comedy video to the composer ( $w w w^{10}$ n.d.). 
Table 2 Plagiarised Tamil songs before 1990 (with their originals)

Plagiarised Tamil Song

Film: Mouna Ragam

Song: Theme music (Please click here)

Composer: Ilaiyaraaja

Release date: 15th August 1986

Film: Oru Kaidhiyin Dairy

Song: A, B, C nee Vasi (Please click here)

Composer: Ilaiyaraaja

Release date: 14th January 1985

Film: Chinna Veedu

Song: Chittu kuruvi (Please click here)

Composer: Ilaiyaraaja

Release date: 11th November 1985

Film: Murattukaalai

Song: Entha poovilum (Please click here)

Composer: Ilaiyaraaja

Release date: 20th December 1980

Film: Kalyanaraman

Song: Kadhal Vandhiruchu (Please click here)

Composer: Ilaiyaraaja

Release date: 1st January 1979

Film: Ninaithaley Innikum (high sampling activity)

Song: Sayanora (Please click here)

Composer: MS Viswanathan

Release date: 14 April 1979

Film: Priya

Song: Akkarai seemai (Please click here)

Composer: Ilaiyaraaja

Release date: 19th December 1978

Film: Priya

Song: Darling! Darling (Please click here)

Composer: Ilaiyaraaja

Release date: 19 December 1978

Film: Avan Oru Sarithiram

Song: En Manadhu Ondru (Please click here)

Composer: MS Viswanathan

Release date: 19th December 1977

Film: Athey Kankal

Song: Oh Oh Ethanai Azhagu (Please click here)

Composer: Veda

Release date: 26th May 1967

Film: Athey Kankal

Song: Bhoom Bhoom (Please click here)

Composer: Veda

Release date: 26th May 1967

Film: Kathalithal pothuma

Song: Konjam Nilladi (Please click here)

Composer: Veda

Release date: 1st November 1967

Film: Nadodi

Song: Ulagam enkum (Please click here)

Composer: MS Viswanathan

Release date: 1966

Film: Pudhiya Paravai

Song: Partha gnapakam (Please click here)

Composer: MS Viswanathan

Release date: 12th September 1964
Original song or music

Album title: Flashdance

Song: Love Theme - Please click here

Composer: Giorgio Moroder

Release date: 30th June 1983

Album title: Lithuanian Orchestra

Song: - L'Arlesienne (Please click here)

Composer: Bizet

Release date: 1 October 1872

Album title: Symphony No. 9

Song: Scherzo: Molto Vivace (Please click here)

Composer: Antonín Dvořák

Release date: 1893

Album title: Cancione et Danza

Song: Danza (Please click here)

Composer: Antonio Ruiz-Pipó

Written: Between 1918 and 1972

Album title: Uriah

Song: Kites (Please click here)

Composer: Simon Dupree

Release date: 26 October 1967

Album title: Mama Mia

Song: Mama Mia (Please click here)

Composer: ABBA

Release date: 21 April 1975

Album title: The Big Sound

Song: Kites (Please click here)

Composer: Simon Dupree

Release date: 26 October 1967

Album title: Take the heat off me

Song: Sunny (Please click here)

Composer: Boney M (written by B Hebb)

Release date: 1976

Album title: Für Elise

Song: Für Elise (Please click here)

Composer: Beethovan

Release date: 1867

Album title: Walk, Don't Run (Vol 2)

Song: Pedal pushers (Please click here)

Composer: Ventures

Release date: 1867

Album title: Mary Popins

Song: Chim Chim Cher-ee (Please click here)

Composer: Sherman Brothers

Release date: 1864

Album title: Quando - Englebert Humberdinck

Song: Quando, Quando, Quando (Please click here)

Composer: Tony Renis

Release date: 1962

Album title: The Kingston Trio

Song: Tom Dooley (Please click here)

Composer: The Kingston Trio

Release date: 1958

Album title: Released as single

Song: Sway (Please click here)

Composer: Dean Martin

Release date: 1954 
Table 2 (continued)

Plagiarised Tamil Song

Film: Aravalli

Song: Sinapennana pothily (Please click here)

Composer: G. Ramanathan

Release date: 22nd October 1957

Film: Rajee en kanmani

Song: Mallikai poo jathi roja (Please click here)

Composer: Hanumantha Rao

Release date: 29th January 1954
Original song or music

\author{
Album title: The Man Who Knew Too Much \\ Song: Que. Sera, Sera (Please click here) \\ Composer: Jay Livingston (Film) \\ Release date: 1956 \\ Album title: Spanish folk (Copla) Song \\ Song: La Violetera (Please click here) \\ Composer: José Padilla/Sara Montiel \\ Release date: 1931
}

*The famous composers have been identified by different colours [Green=Ilaiyaraaja (IR); Blue = AR Rahman (ARR); Purple= MS Viswanathan (MSV)]

Our conversations with the whistle-blowers revealed that most of the mainstream media are turning a blind eye to his "pathological plagiaristic behaviour" (as put by one interviewee). We have also managed to study one of the videos in which HJ was interviewed (www ${ }^{11}$ n.d.), in which the interviewer questioning him about his high level of "sampling" within his own songs. His reply was "that is my style, my trademark; people recognise me with that style...... you can even call this as my own brand". Interestingly, the interviewer never questioned anything about the blatant plagiarised songs from several Western (and other) music artists. Main reason may be the fact that $\mathrm{HJ}$ has gained a reputation amongst general public. Many of his songs are hit records, not only due to the fact that the original melodies themselves were attractive but also many Indian cinema goers are prepared to overlook his plagiaristic activities and accept his music. Questioning a musician who is highly reputed and worshiped by millions of the cinemagoers would result in serious repercussions from his fans.

This is true for other famous music directors like IR, ARR and MSV. One music critic stated, "our people are not that stupid, they all know these songs are copied from world famous melodies, yet they enjoy the satisfaction of listening them in their own language" "this is the reason they are 'tolerating' plagiarised music". One of HJ's fans stated "entertainment is different from scholarly activities" he further warned us, "cinema is an entertainment (so is the music), so treat them as they are; do not expect integrity; just enjoy the songs (or let us enjoy it)". Another HJ's fans said, "music is a global language, and there is always a possibility of similarities the melodies of two different songs, these are accidental - just enjoy the music". From these conversations it was clear that many of his fans are prepared to overlook plagiaristic activities. In fact, it was difficult for them to understand the integrity as well as copyright issues behind this theft.

Amongst the four famous Tamil music composers (namely HJ, IR, ARR and MSV), the latter two were careful when they mix or sample other music (their songs are listed in Tables 1 and 2 highlighted as blue and purple respectively). They either slightly changed the rhythm incorporating their own ideas or incorporated other tune in the middle of the song. The music maestro ARR has also copied from famous English and Arabic songs. The extent of his plagiaristic activities is limited, and he is clever enough to incorporate music "ripped off" from other songs. Therefore, it is difficult to prove with pinpoint accuracy. Yet our research has shown that some of his songs are created beyond sampling activity. On the other hand, Ilaiyaraja (IR), another music Maestro, has been in cinematic music industry since 1970's. He has earned followers and fans from all over the world. In 2015, he has secured a court order against others using his works without his consent (www ${ }^{12}$ n.d.). Also, in 2017, IR went to such as extent of serving a legal notice (reminding copyright law) to one of his singers, Mr. SP Balasubramanian (SPB) for performing his (IR's) compositions without his 
permission (Hindu 2017). Whilst IR is too careful about protecting his composition, he never bothered about copyrights of melodies that he copied from international artists. Our research has shown several of his early songs have been plagiarised from Western and other music videos and songs (highlighted in green in Tables 1 and 2).). One of our interviewees said, "he was notorious in stealing two or more songs and mixing to avoid detection". He further added "there are no internet those days, and the world were not as close as now" "This together with limited availability of international music to general public made it easier for these composers to get away with plagiarising". We also searched for plagiarised songs before 1990. In fact, we were able to detect plagiarised songs as far as 1954 onwards. Although the extent of plagiarised music was not found to be that widespread, which may be due to the fact that many of these songs were composed before the internet era, and we may not be able to detect them in the YouTube ${ }^{\circledR}$.

Looking at the famous composers in previous era, we also managed to select some songs composed by the veteran music director late MSV (highlighted in purple in Table 2). He composed songs for over 700 Tamil films during his music career between 1960 and 2013.

As can be seen from the examples given in Table 2, potentially plagiarised songs by MSV only contain a portion of the original melody; he then incorporates his own tune for the rest of his song, makes it difficult to prove. Apart from these, we have identified some plagiarised ancient songs by various composers when the Indian cinema was at its infancy. The oldest evidence of music plagiarism was detected in a film released in 1954 in a film called "Rajee en Kanmani" (the last song in Table 2). Its original song was originally composed in 1914 by a Spanish artist called José Padilla. It was interesting to note the melody is cleverly copied in the age when gramophone was the only source for music. Overall, within the duration of this study, we identified several different plagiarised (or heavily sampled) Tamil songs from different eras. We also checked to see whether any of these identified songs were either mere coincidence, reproduced with permission, or composed by obtaining exclusive rights or collaborations. Our searches have not produced any evidences for these. As stated in the introduction, some (but not all) of these composers have claimed that they have been influenced by the original tune. Indeed, we do accept the fact that the resemblances of two melodies are mainly because the combination of chords (or "Thalas" in Carnatic music) are limited (McDonagh 2012; Stav 2014). In fact, our analysis of notes and melodies shows that the songs listed herein resemble in substantial parts of the original music. It is also worth noting that in India, there are established laws on originality requirement and copyright within India (Nehaluddin and Chaturvedi 2013). However, it is not clear whether these laws are being abided by these composers. Therefore, we intend to bring public awareness by publishing this study, and indirectly show to those composers that the focus on music plagiarism is increasing.

As for "excuses" given by these composers, they varied from mere denial to blatant acceptances claiming, "Nothing really comes from scratch". General public and investigative journalists have questioned these artists about some of these activities. Yet these incidences were either unreported or blacked out by the media. The most popular excuse is "the director wanted me to use that melody, so I used it". Accused of blatant plagiarism, another artist tweeted "I work with a lot of music producers worldwide and therefore I am influenced by their music" (www ${ }^{12}$ n.d.). In fact, one interviewee noted many accused artists come with the excuse as "I was inspired by the original song and it has affected my thoughts". Another contributing factor for this misconduct is the original Western artists, may never even know that their songs are being copied; making it easier to continue with these activities without any lawsuits.

None of the composers we contacted replied with any justification. It is understandable that their songs are popular amongst music lovers because they either do not know these songs 
being plagiarised (or sampled) or are happy to overlook this. Due to this fame, these composers are getting away with plagiarism.

Lastly but most importantly, we would like to point out, Dravidian culture has long standing esteem of producing original songs. Several cinema songs themselves were praised for their authenticity and obtained international awards. Quoting a Tamil cinema sources, the Wikipedia® has estimated over 5000 Tamil films were produced in the twentieth century alone (www ${ }^{14}$ n.d.; See also Velayutham 2008). Also, one of our interviewees estimated approximately 40 Tamil films per year are being released in the twenty-first century. Each film would usually have at least 4 to 5 songs. On the basis of this estimation, the proportion of plagiarised songs presented herein are negligible (roughly $0.6 \%$ ). Therefore, these songs can only be considered as exception than norm. While authors agree that there may be other songs undetected for plagiarism, it is not fair to accuse all composers for plagiarism. We also wish to point out, that there are at least 20 different cinematic industries established in respective languages in India. Therefore, addressing the issue in all these industries would be a Herculean task. Therefore, this study only investigated the cinema music in one language. However, this does not mean there is no plagiarism in cinema music of other languages. As individuals who strongly believe in academic integrity and fair play, we felt, it is our duty to highlight these activities and we do believe this manuscript would enhance public awareness by highlighting the issue of "music plagiarism".

\section{Concluding Remarks}

This preliminary investigation has identified an extensive list of plagiarised songs within one cinematic industry in India from 1954 until now. These songs have shown "beat-by-beat" similarities to the tones, and/or rhythms of the original songs. Whilst agreeing to the fact that some of these might be mere coincidences, or produced by inspirational impacts, the sheer similarities of these songs and their extent warrants further investigations. We have also highlighted the similarities of these music files (videos and/or audio recordings for comparison) and provided links (in the online version) for the readers/listeners to come to their own conclusions.

Acknowledgements Authors wish to thank all vigilantes who have directly or indirectly contributed to this article by highlighting the issues and taking part in the interviews.

Open Access This article is licensed under a Creative Commons Attribution 4.0 International License, which permits use, sharing, adaptation, distribution and reproduction in any medium or format, as long as you give appropriate credit to the original author(s) and the source, provide a link to the Creative Commons licence, and indicate if changes were made. The images or other third party material in this article are included in the article's Creative Commons licence, unless indicated otherwise in a credit line to the material. If material is not included in the article's Creative Commons licence and your intended use is not permitted by statutory regulation or exceeds the permitted use, you will need to obtain permission directly from the copyright holder. To view a copy of this licence, visit http://creativecommons.org/licenses/by/4.0/.

\section{References}

Behrens, F. (2004). A mathematical look at musical plagiarism art times- blog posted on art timesjournal.com https://www.arttimesjournal.com/music/mathematical.htm - Accessed on 30 March 2019.

Glendinning (2014). Comparison of policies for Academic Integrity in Higher Education across the European Union IPPHEAE Project Consortium. International Journal of Academic Integrity. 10(1) http://plagiarism. 
cz/ippheae/files/D2-3-00\%20EU\%20IPPHEAE\%20CU\%20Survey\%20EU-wide\%20report.pdf - Accessed on 1 January 2019.

Indywood Report (2016). https://www2.deloitte.com/content/dam/Deloitte/in/Documents/technology-mediatelecommunications/in-tmt-indywood-film-festival-noexp.pdf

Keyes, J.M. (2014). Musical musings: The case for rethinking music copyright protection, 10 Mich. Telecomm. Tech. L. Rev. 407.

Keyt, A. (1988). An improved framework for music plagiarism litigation, 76 Calif. L. Rev. 421.

McDonagh, L. J. (2012). Is the creative use of musical works without a Licence acceptable under copyright law? International Review of Intellectual Property and Competition Law (IIC), 4, 401-426.

Nehaluddin, A., \& Chaturvedi, S. (2013). Originality requirement and copyright regime of music: A comparative overview of Indian perspective. Information \& Communications Technology Law, 22(2), 132-145. https://doi.org/10.1080/13600834.2013.814238.

Nettl, B. (2010), Tala, Music, Encyclopædia Britannica - https://www.britannica.com/art/tala

Press council of India - UNESCO (2010) - http://www.legalserviceindia.com/copyright/music-copyright-inIndia.htm - Accessed on 1 March 2018.

Stav, I. (2014). Musical plagiarism: A true challenge for the copyright law, 25 DePaul J. Art, Tech. \& Intell. Prop. L. 1 Available at: http://via.library.depaul.edu/jatip/vol25/iss1/2

The Hindu (2017) https://www.thehindu.com/entertainment/movies/what-the-spat-between-ilaiyaraaja-and-spbis-really-about/article17665382.ece - Accessed on 12 December 2018.

Velayutham, S. (2008). Tamil cinema: The cultural politics of India's other film industry. Abingdon: Routledge. www ${ }^{1}$ (n.d.). https://dictionary.onmusic.org/terms/2138-melody - Accessed on 12 March 2019.

www ${ }^{2}$ (n.d.). https://www.youtube.com/watch?v=JuM7hObGjWI - Accessed on 30 March 2019.

$w_{w} w^{3}$ (n.d.). https://www.youtube.com/watch?v=aeRXvjUNUcQ - Accessed on 30 March 2019.

www 4 (n.d.). https://www.wipo.int/treaties/en/ip/wct/ - Accessed on 11 December 2018.

$\mathrm{www}^{5}$ (n.d.). https://www.youtube.com/watch?v=03wS2tdlZtE - Accessed on 10 January 2019.

$\mathrm{www}^{6}$ (n.d.). https://www.youtube.com/watch?v=c9r1Vfb51X8\&list=RDc9r1Vfb51X8\&start_radio $=1$ Accessed on $10^{\text {th }}$ January 2019.

www $^{7}$ (n.d.). https://consequenceofsound.net/2018/01/10-famous-instances-of-alleged-music-plagiarism/ Accessed on 10 March 2018.

www ${ }^{8}$ (n.d.). https://rajasmusic.wordpress.com/2013/12/11/a-symphony-of-success-ilaiyaraaja-interview-in1993/ - Accessed on 30 March 2019.

www ${ }^{9}$ (n.d.). http://www.newindianexpress.com/entertainment/tamil/2019/jan/17/this-harris-jayaraj-song-fromdev-may-sound-familiar-to-a-michael-jackson-fan-1926352.html - Accessed on 12 March 2019.

www ${ }^{10}$ (n.d.). https://www.youtube.com/watch?v=n0xhIlOJ-JQ - Accessed on 10 February 2019.

www ${ }^{11}$ (n.d.). https://www.youtube.com/watch?v=cmpO\%2D\%2D7LADw- Accessed on 24 February 2019.

www ${ }^{12}$ (n.d.). https://www.thehindu.com/news/cities/chennai/ilayaraja-asserts-his-copyright-oversongs/article6960931.ece - Accessed in India on 10 December 2018.

www ${ }^{13}$ (n.d.). https://regional.pinkvilla.com/tamil/news/kalyanu-vayasu-copy-sannans-dont-lie-anirudhravichander-hits-back-haters/ - Accessed on 30 March 2019.

www ${ }^{14}$ (n.d.). https://en.wikipedia.org/wiki/Tamil_cinema - Accessed on 30 March 2019.

Publisher's Note Springer Nature remains neutral with regard to jurisdictional claims in published maps and institutional affiliations.

\section{Affiliations}

\section{Paneerselvam Umamaheswaran ${ }^{1} \cdot$ Sharavan Ramachandran $^{2} \cdot$ Shivadas D. $^{2}$ Sivasubramaniam $^{3}$}

1 News7-Tamil Tamil Television, Kodambakkam High Road, Chennai, India

2 Health Sciences Centre, Amarillo, TX, USA

3 School of Human Sciences, University of Derby, Derby DE22 1GB, UK 